\title{
Problems of Household Waste Disposal
}

\author{
Ruchi Kaundal and Avinash Sharma \\ Department of Family Resource Management, College of Home Science, CSK HPKV, \\ Palampur 176 062, Himachal Pradesh, India
}

KEYWORDS Environmental Pollution. Household Waste. Waste Recycling

\begin{abstract}
The study was conducted in Palampur, Himachal Pradesh. Multi-stage stratified random sampling was used to draw a sample of 108 respondents. Based on sample survey, the study reveals that the garbage disposal outside the house was a major problem. Polythene was burnt along with other waste in both the communities. Waste recycling awareness was found to be higher in teaching community as compared to non-teaching community.
\end{abstract}

\section{INTRODUCTION}

Man is behind every development endeavor. The large scale production and improper disposal of waste has become a source of pollution and further accumulation of garbage has resulted in serious deterioration in quality of life and the ecological balance. Many diseases like cholera and gastro-enterits have been reported due to lack of proper collection and disposal of solid waste, insanitary condition and unsafe drinking water (Marudachalam, 1990). An emphasis need to be given on the need of systematic waste management, cost effective methods, environmentally and procedurally safe and acceptable at low maintenance level. Therefore, the objectives of the study were:

1. To examine the problems of household waste

2. To study level of awareness regarding household waste utilization.

\section{MATERIALS AND METHODS}

Descriptive survey design was used to achieve the objectives. The study was conducted in campus area of CSK HPKV, Palampur. A multi-stage stratified random sampling was used to select residential sites, residential colonies and ultimate 108 female respondents from teaching and nonteaching communities. Both primary and secondary data were collected. The primary data were collected with the help of structured and pre-tested interview schedule through personal interview method. The data were tabulated and analyzed with the help of appropriate statistical tools.

\section{RESULTSAND DISCUSSION}

On the basis of sample survey, it was found that all the respondents disposed off the polythene in the open and used to burn them along with other waste. The improper disposal of plastic sometimes gave a dull and dreary look at the disposal site besides devastating effect on the environment as polythene is non biodegradable in nature (Table 1).

The huge quantity of waste production and improper methods of waste disposal were found to be causing environmental pollution in the campus. This has direct and indirect effects on human, animal and plant life alike. The study revealed that about three-fourth of respondents considered choking of drainage system with garbage as a major problem faced outside the house (Table 2).

The drains were usually choked with polythene or domestic garbage. It was noted that disposal of domestic garbage in polythene had more chances of choking of drains (Patial, 2001).

The foul smell emitted by accumulated garbage polluting the environment was pointed out to be a major problem. The garbage thrown

Table 1: Distribution of respondents based on disposal pattern of polythene

\begin{tabular}{|c|c|c|c|}
\hline \multirow[t]{2}{*}{ Particulars } & \multicolumn{3}{|c|}{ Respondents category } \\
\hline & Teaching & Non-teaching & Total \\
\hline \multicolumn{4}{|c|}{ Burning of Polythene } \\
\hline Yes & $\begin{array}{c}53 \\
(100.00)\end{array}$ & $\begin{array}{c}55 \\
(100.00)\end{array}$ & $\begin{array}{l}108 \\
(100.00)\end{array}$ \\
\hline No & - & - & - \\
\hline \multicolumn{4}{|c|}{ Method of Burning } \\
\hline Along with other & $\begin{array}{l}\text { waste53 } \\
\quad(100.00)\end{array}$ & $\begin{array}{c}55 \\
(100.00)\end{array}$ & $\begin{array}{l}108 \\
(100.00)\end{array}$ \\
\hline Separately & - & - & - \\
\hline \multicolumn{4}{|c|}{ Distance of Disposal Site $(m)$ from Residence } \\
\hline$<100$ & $\begin{array}{c}53 \\
(100.00)\end{array}$ & $\begin{array}{l}48 \\
(87.27)\end{array}$ & $\begin{array}{l}101 \\
(93.52)\end{array}$ \\
\hline$>100$ & - & $\begin{array}{c}7 \\
(12.73)\end{array}$ & - \\
\hline
\end{tabular}

Figures in parentheses are percentages 
Table 2: Distribution of respondents based on satisfaction with disposal practices

\begin{tabular}{|c|c|c|c|}
\hline \multirow[t]{2}{*}{ Particulars } & \multicolumn{3}{|c|}{ Respondent category } \\
\hline & Teaching & $\begin{array}{l}\text { Non- } \\
\text { teaching }\end{array}$ & Total \\
\hline \multicolumn{4}{|c|}{ Satisfaction with Disposal Practices Inside the House } \\
\hline Yes & $\begin{array}{c}53.0 \\
(100.00)\end{array}$ & $\begin{array}{c}55.0 \\
100.00)\end{array}$ & $\begin{array}{l}108 \\
100.00)\end{array}$ \\
\hline No & - & - & - \\
\hline \multicolumn{4}{|l|}{ Outside the House } \\
\hline Yes & $\begin{array}{l}8 \\
(15.09)\end{array}$ & $\begin{array}{c}7 \\
(12.73)\end{array}$ & $\begin{array}{l}15 \\
(13.89)\end{array}$ \\
\hline No & $\begin{array}{l}45 \\
(84.91)\end{array}$ & $\begin{array}{c}48 \\
(87.27)\end{array}$ & $\begin{array}{c}93 \\
(86.11)\end{array}$ \\
\hline \multicolumn{4}{|c|}{ Problems Outside the House } \\
\hline $\begin{array}{l}\text { Accumulation of } \\
\text { garbage leads to choking of } \\
\text { drainage }\end{array}$ & $\begin{array}{l}40 \\
(75.47)\end{array}$ & $\begin{array}{l}44 \\
(80.00)\end{array}$ & $\begin{array}{l}84 \\
(77.78)\end{array}$ \\
\hline $\begin{array}{l}\text { Garbage emits foul smell and } \\
\text { pollutes environment }\end{array}$ & 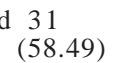 & $\begin{array}{l}35 \\
(63.64)\end{array}$ & $\begin{array}{l}66 \\
(61.11)\end{array}$ \\
\hline $\begin{array}{l}\text { Attract stray dogs, animals } \\
\text { and birds }\end{array}$ & $\begin{array}{l}\text { s } 26 \\
(49.06)\end{array}$ & $\begin{array}{l}23 \\
(41.82)\end{array}$ & $\begin{array}{l}49 \\
(45.37)\end{array}$ \\
\hline Cause of many diseases & $\begin{array}{l}11 \\
(20.75)\end{array}$ & $\begin{array}{l}20 \\
(36.36)\end{array}$ & $\begin{array}{l}31 \\
(28.70)\end{array}$ \\
\hline
\end{tabular}

Figures in parentheses are percentages.

was very near to residential colonies (upto 100 metres) thereby emitting foul smell particularly in summer and rainy season. A few respondents (nearly $29 \%$ ) considered the importance of garbage as a cause for many diseases. However, Sharma (2002) reported that in Shimla, waste indiscriminately thrown into nullahs and on the roadside contaminated the water supply and stomach ailment had increased in the town. Further, besides being eyesore, the garbage dumps were posing health and environmental hazard for million of people residing in Delhi
(Malik, 1995). All the respondents considered the public garbage and its disposal a problem. Mahajan (1997) observed that garbage from commercial and domestic areas was a problem in Shimla town.

Since the problem of waste has become serious, it is necessary to create an environmental consciousness among the people. The data from the study revealed that waste-recycling awareness was found to be higher in teaching community which could be related to variation in education level of both the communities. But the adoption of waste recycling and reuse techniques were negligible which might be due to drudgery involved in the work and the attitudinal factors like readiness to adopt new techniques, problem of waste segregation etc. Sundari and Saradha also supported that there is greater awareness on environmental issues in urban areas besides, this the households are wholly dependent on external agents to do the needful. All the respondents agreed for placement of community bins at appropriate distance from residential colonies to prevent foul smell emitted from the waste thrown in the open (Table 3).

Only one third of the respondents agreed to the suggestion of segregation of waste before final disposal. This may be due to overburdening of homemakers with their domestic responsibilities. They must be made more aware of the importance of adoption of segregation of waste before final disposal. There is a need for creating separate community bins for biodegradable and nonbiodegradable waste material to solve the drudgery

Table 3: Suggestions for effective disposal practices particulars

\begin{tabular}{|c|c|c|c|c|c|c|}
\hline & \multicolumn{6}{|c|}{ Respondents category } \\
\hline & \multicolumn{2}{|c|}{ Teaching } & \multicolumn{2}{|c|}{ Non-teaching } & \multicolumn{2}{|c|}{ Total } \\
\hline & Yes & No & Yes & No & Yes & No \\
\hline $\begin{array}{l}\text { Placement of bins at appropriate } \\
\text { distance }\end{array}$ & $\begin{array}{c}53 \\
(100.0)\end{array}$ & $\begin{array}{l}- \\
-\end{array}$ & $\begin{array}{c}55 \\
(100.00)\end{array}$ & - & $\begin{array}{l}108 \\
(100.00)\end{array}$ & - \\
\hline $\begin{array}{l}\text { Segregation of waste before } \\
\text { disposing }\end{array}$ & $\begin{array}{l}18 \\
(33.96)\end{array}$ & $\begin{array}{l}35 \\
(66.04)\end{array}$ & $\begin{array}{l}25 \\
(45.45)\end{array}$ & $\begin{array}{l}30 \\
(54.55)\end{array}$ & $\begin{array}{l}43 \\
(39.81)\end{array}$ & $\begin{array}{l}65 \\
(60.19)\end{array}$ \\
\hline $\begin{array}{l}\text { Separate dustbins for separate } \\
\text { Waste }\end{array}$ & $\begin{array}{l}18 \\
(33.96)\end{array}$ & $\begin{array}{l}35 \\
(66.04)\end{array}$ & $\begin{array}{l}25 \\
(45.45)\end{array}$ & $\begin{array}{l}30 \\
(54.55)\end{array}$ & $\begin{array}{c}43 \\
(39.81)\end{array}$ & $\begin{array}{l}65 \\
(60.19)\end{array}$ \\
\hline $\begin{array}{l}\text { Effective waste management } \\
\text { at household level }\end{array}$ & $\begin{array}{l}19 \\
(35.85)\end{array}$ & $\begin{array}{l}34 \\
(64.15)\end{array}$ & $\begin{array}{l}11 \\
(20.00)\end{array}$ & $\begin{array}{l}44 \\
(80.00)\end{array}$ & $\begin{array}{l}30 \\
(27.78)\end{array}$ & $\begin{array}{l}78 \\
(72.22)\end{array}$ \\
\hline $\begin{array}{l}\text { Effective waste management } \\
\text { at community level }\end{array}$ & $\begin{array}{l}41 \\
(77.36)\end{array}$ & $\begin{array}{l}12 \\
(22.64)\end{array}$ & $\begin{array}{l}35 \\
(63.64)\end{array}$ & $\begin{array}{c}20 \\
(36.36)\end{array}$ & $\begin{array}{l}76 \\
(70.37)\end{array}$ & $\begin{array}{l}32 \\
(29.63)\end{array}$ \\
\hline $\begin{array}{l}\text { Providing education for waste } \\
\text { management }\end{array}$ & $\begin{array}{l}48 \\
(90.57)\end{array}$ & $\begin{array}{l}5 \\
(9.43)\end{array}$ & $\begin{array}{l}54 \\
(98.18)\end{array}$ & $(1.82)$ & $\begin{array}{l}102 \\
(94.44)\end{array}$ & $\begin{array}{l}6 \\
(5.56)\end{array}$ \\
\hline Financial help & $\begin{array}{l}2 \\
(3.77)\end{array}$ & $\begin{array}{c}51 \\
(96.23)\end{array}$ & - & $\begin{array}{c}55 \\
(100.0)\end{array}$ & $\begin{array}{l}2 \\
(1.85)\end{array}$ & $\begin{array}{l}106 \\
(98.15)\end{array}$ \\
\hline
\end{tabular}

Figures in parentheses are percentages. 
in segregation. The segregation of household waste at the source and its collection in Solan town had been implemented for proper use of waste (Anonymous, 2001).

About seventy per cent of respondents agreed for effective waste management at community level instead of domestic level. The possible reason for this may be attitude of an individual to escape from the responsibilities. Nearly ninety four per cent of respondents were in favour of providing education for waste management to keep the campus clean and environment sound. Some of the respondents in teaching community suggested need of financial help from university/ government for construction of pits or community bins for waste disposal at community level.

\section{REFERENCES}

Anonymous: Clean city campaign launched in Solan. Indian Express, December 27 (2001).

Mahajan, J.: Garbage, air pollution bedevil Shimla. The Tribune, May 17 (1997).

Malik, I.: No time to waste. Indian Express, September 17 (1995).

Marudachalam, V.M. Environmental degradation of societal nature in India: A case study of Madras. Man and Development, XII(4): 82-91 (1990).

Patial, S.: Volunteers step in to rid the town of polythene. Indian Express, December 20 (2001).

Sharma, S.P.: Bypass turns into waste dump. The Tribune, February 17 (2002).

Sundari, S. and Saradha, K.K.: Domestic and commercial solid waste management. The Indian Journal of Social Work, 62(1): 67-88 (2001). 